TECHNICAL TRANSACTIONS 1/2017

CZASOPISMO TECHNICZNE 1/2017

CHEMISTRY

DOI: $10.4467 / 2353737$ XCT.17.003.6100

Grzegorz Kurowski (kurowski@chemia.pk.edu.pl)

Otmar Vogt

Jan Ogonowski

Institute of Organic Chemistry and Technology, Faculty of Chemical Engineering

and Technology, Cracow University of Technology

\title{
ACTIVE INGREDIENTS IN PAINT STRIPPERS
}

SUBSTANCJE AKTYWNE W PREPARATACH

DO USUWANIA POWŁOK LAKIERNICZYCH

\section{Abstract}

The papers presents the study on the application of acetals as active ingredients in paint strippers. The formulation was prepared and the ability to wrinkling of the shell was rated. The ability to wrinkling of the shell was rated by examining the force required to detachment the coating.

Keywords: paint stripper, active ingredients, acetals

\section{Streszczenie}

W artykule przedstawiono badania dotyczące zastosowania acetali jako substancji aktywnych w preparatach do usuwania powłok lakierniczych. Sporządzono preparaty oraz oceniono ich zdolność do odspajania powłoki. Zdolność do odspajania powłoki oceniano badając siłę potrzebną do oderwania powłoki.

Słowa kluczowe: preparaty do usuwania powłok lakierniczych, substancje aktywne, acetale 


\section{Introduction}

Since the Council of the European Union has banned the use of methylene chloride in paint removers [1], it was necessary to find substances, which are able to replace this compound. Currently, active ingredients that are used include compounds, such as $\mathrm{N}$-methylpyrrolidone [2-6] and benzyl alcohol [7-12] as well as alkylene carbonates, such as propylene carbonate or ethylene carbonate [13-15]. Furthermore, carboxylic acid esters are also used. In patents, benzoic acid methyl ester [16] as well as methyl esters of dicarboxylic acids, such as succinic acid, glutaric acid and adipic acid [17-19], are described. Moreover we can use such esters like: ethyl acetate, butyl acetate, ethyl 3 -ethoxypropionate and 1-methoxy-2-propyl acetate. However, the most preferred is ethyl 3-ethoxypropionate $[20,21]$. The patents also describe such compounds as alkyl derivatives of carboxylic acid amides, dicarboxylic acid and hydroxycarboxylic acids [22], alkoxylated aromatic alcohols [23, 34].

Research on this topic is also being conducted at the Institute of Organic Chemistry and Technology of the Department of Chemical Engineering and Technology at the Cracow University of Technology. In our research, we study the usefulness of acetals as active ingredients.

The topic of this study was to check the influence of different active substances from the group of acetals on the ability to remove the coating. For comparison, we used the most commonly used active ingredients (N-methylpyrrolidone and benzyl alcohol).

\section{Materials and methods}

\subsection{The paint removers}

In the study, paint removers based on the author's recipe were used. The way of their preparation was different for the used active ingredient. For the study, we used substances with a different partition coefficient $(\log \mathrm{P})$. Due to the used different active ingredients, we used preparations in two forms - gel and emulsion.

In the study, the following substances were used: N-methylpyrrolidone $(\log \mathrm{P}-0.40)$, dimethoxymethane $(\log \mathrm{P}-0.26)$, dioxolane $(\log \mathrm{P}-0.06)$, benzyl alcohol $(\log \mathrm{P} 1.03)$, diethoxyethane $(\log \mathrm{P} 1.14)$, cyclohexanone ethylene ketal $(\log \mathrm{P} 1.35)$, benzaldehyde ethylene acetal $(\log \mathrm{P} 1.63)$, dipropoxyethane $(\log \mathrm{P} 2.21)$, dibutoxyethane $(\log \mathrm{P} 3.27)$.

\subsection{Preparations in gel form}

Dioxolane and $\mathrm{N}$-methylpyrrolidone were used in the gel preparation as active ingredients. 
Table 1. The composition of the gel preparation

\begin{tabular}{|c|c|}
\hline Substance & Composition [\% wt.] \\
\hline Active ingredient & 42.2 \\
\hline Adduct & 14.0 \\
\hline Water & 14.0 \\
\hline Frakol & 13.5 \\
\hline Ester solvent & 6.7 \\
\hline Modisurf Clarity & 4.8 \\
\hline Methocel & 4.8 \\
\hline
\end{tabular}

\subsection{Preparations in emulsion form}

Table 2. The composition of the emulsion preparation

\begin{tabular}{|c|c|}
\hline Substance & Composition [\% wt.] \\
\hline Active ingredient & 45.6 \\
\hline Methyl esters of rapeseed oil & 13.6 \\
\hline Hydrogen peroxide & 13.6 \\
\hline Candelila wax & 9.1 \\
\hline Ester solvent & 6.8 \\
\hline Frakol & 6.8 \\
\hline Tween 40 & 2.9 \\
\hline Glycerol monostearate & 1.6 \\
\hline
\end{tabular}

Dimethoxymethane, dioxolane, benzyl alcohol, diethoxyethane, cyclohexanone ethylene ketal, benzaldehyde ethylene acetal, dipropoxyethane, dibutoxyethane were used in the emulsion preparation as active ingredients.

\subsection{Plates}

In the study, we used five types of plates. Two plates (blue, white) were delivered by Fiat Auto Poland Company in Tychy. The blue plate was painted with solvent-based acrylic paint. The white plate was painted with waterborne acrylic paint. The other two plates (green and brown) were painted with melamine formaldehyde paints. The last plate (epoxy) was painted with epoxy paint. The three last paints are used for roof covering. 


\subsection{The study of coating detachment}

The paint remover was applied on the plate. In each case, the formulation was applied to the surface of $9 \pm 0.3 \mathrm{~cm}^{2}$. Due to the next steps of the procedure, we adopted a uniform square shape for the area of application of the preparation. The preparation was left on the surface for 24 hours. After this time, the preparation was removed and the effect on the surface was rated. A metal badge with an area of $9 \pm 0.3 \mathrm{~cm}^{2}$ was glued next to the coating. The glue was left for 48 hours to dry completely. After this time, the force required to detach the coating was measured. The measurement was performed on Zwick 1445 apparatus intended for testing the strength of materials. In the study, a constant crosshead speed of $50 \mathrm{~mm} / \mathrm{min}$ was applied.

\section{Results and discussion}

\subsection{Results of study of the interaction on the coating}

In the case of the green plate, all active ingredients caused wrinkling of the shell. A similar situation took place in the case of the brown plate. An exception was diethoxyethane, which did not cause wrinkling of the shell. A different situation occurred in the case of the blue, white and epoxy plates. In those cases, wrinkling of the shell caused only dioxolane (emulsion). The wrinkling of the shell also caused dimethoxymethane, but only in the case of the blue plate. In the case of the epoxy plate, wrinkling of the shell also caused the preparation with benzyl alcohol. In other cases, the preparation did not cause any wrinkling of the shell.

\subsection{Results of coating detachment study}

In the case of the blue plate, we can see a reduction of the force needed to detach the coating that treated the preparation compared to the coating that did not treat the preparation. The average force required to pull-of the coating, which did not treat the preparation, is $216 \mathrm{~N}$. However, not all layers of the coating are detached. The detachment of all layers of the coating was possible after the action on the coating formulations containing dioxolane (gel), diethoxyethane and benzaldehyde ethylene acetal. The force required to pull-of the coating is $158 \mathrm{~N}$ for dioxolane, $182 \mathrm{~N}$ for diethoxyethane and $136 \mathrm{~N}$ for benzaldehyde ethylene acetal. The preparations with cyclohexanone ethylene ketal and dibutoxyethane caused softening of the shell. It makes it possible to detach the coating of the silver layer with an average force of $148 \mathrm{~N}$ for cyclohexanone ethylene ketal and 121 $\mathrm{N}$ for dibutoxyethane.

Comparing the results with the properties of the compound (partition coefficient of $\mathrm{o} / \mathrm{w} \log \mathrm{P}$ ), we can see that, with an increase of the partition coefficient, the susceptibility to wrinkling of the shell is lower. The preparations containing dioxolane $(\log \mathrm{P}-0.06)$ and 
dimethoxymethane $(\log \mathrm{P}-0.26)$ caused wrinkling of the shell. The preparations containing diethoxyethane $(\log P 1.14)$ and benzaldehyde ethylene acetal $(\log P 1.63)$ caused softening of the shell. This makes it possible to detach all layers of the coating. The preparations containing dipropoxyethane $(\log P 2.21)$ and dibutoxyethane $(\log P$ 3.27) also caused softening of the shell, but this makes possible to detach only one layer of the coating.

\section{Blue plate}

Table 3. Results of coating detachment study for the blue plate

\begin{tabular}{|l|l|l|l|}
\hline \multirow{2}{*}{ Active ingredient } & \multicolumn{2}{c}{ Force } & \multicolumn{1}{c}{ Comments } \\
\cline { 2 - 4 } - & kPa & N & \multicolumn{1}{|c|}{ A part of the coating was detached } \\
\hline Dimethoxymethane & 246.1 & 216.0 & \multirow{2}{*}{ A } \\
\hline Dioxolane (gel) & The coating was wrinkled \\
\hline Dioxolane (emulsion) & 176.2 & 158.6 & All layers of the coating were detached \\
\hline Diethoxyethane & The coating was wrinkled \\
\hline Cyclohexanone ethylene ketal & 159.0 & 147.9 & All layers of the coating were partially detached \\
\hline Benzaldehyde ethylene acetal & 146.6 & 136.4 & All layers of the coating were detached \\
\hline Dipropoxyethane & 147.9 & 133.1 & Coating intact \\
\hline Dibutoxyethane & 139.5 & 121.4 & Coating was detached to the silver layer \\
\hline
\end{tabular}
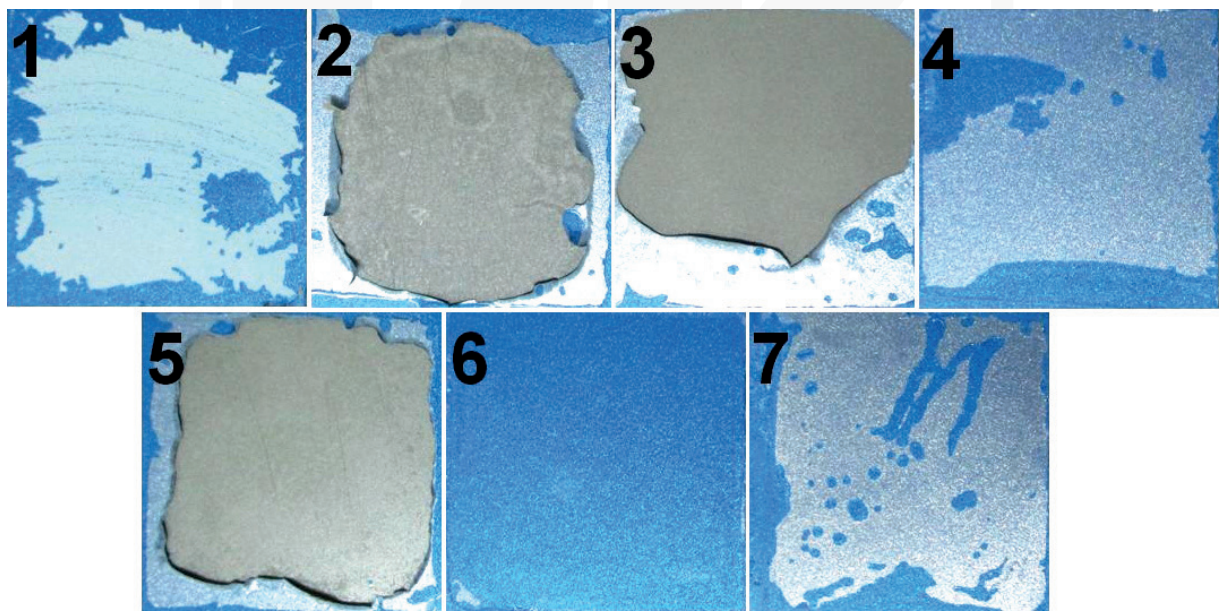

Fig. 1. The plate after study of coating detachment; 1 - reference sample, plate treated the preparation with 2 - dioxolane (gel), 3 - diethoxyethane, 4 - cyclohexanone ethylene ketal, 5 - benzaldehyde ethylene acetal, 6 - dipropoxyethane, 7 - dibutoxyethane 


\section{White plate}

Table 4. Results of coating detachment study for the white plate

\begin{tabular}{|l|l|l|l|}
\hline \multirow{2}{*}{ Active ingredient } & \multicolumn{2}{c|}{ Force } & \multicolumn{1}{c}{ Comments } \\
\cline { 2 - 3 } & $\mathrm{kPa}$ & \multicolumn{1}{c|}{$\mathrm{N}$} & \multicolumn{1}{c|}{ Coating intact } \\
\hline- & 269.0 & 242.1 & Coating \\
\hline N-methylpyrrolidone & 226.4 & 197.0 & The first layer of the coating was detached \\
\hline Dimethoxymethane & 162.3 & 151.0 & All layers of the coating were detached \\
\hline Dioxolane (gel) & 306.3 & 284.9 & Coating intact \\
\hline Dioxolane (emulsion) & The coating was wrinkled \\
\hline Benzyl alcohol & 152.9 & 142.2 & All layers of the coating were detached \\
\hline Diethoxyethane & 63.0 & 56.6 & All layers of the coating were detached \\
\hline Cyclohexanone ethylene ketal & 243.5 & 226.4 & All layers of the coating were detached \\
\hline Benzaldehyde ethylene acetal & 358.2 & 333.1 & All layers of the coating were partially detached \\
\hline Dipropoxyethane & 155.7 & 140.2 & Coating intact \\
\hline Dibutoxyethane & 209.8 & 195.2 & Coating intact \\
\hline
\end{tabular}
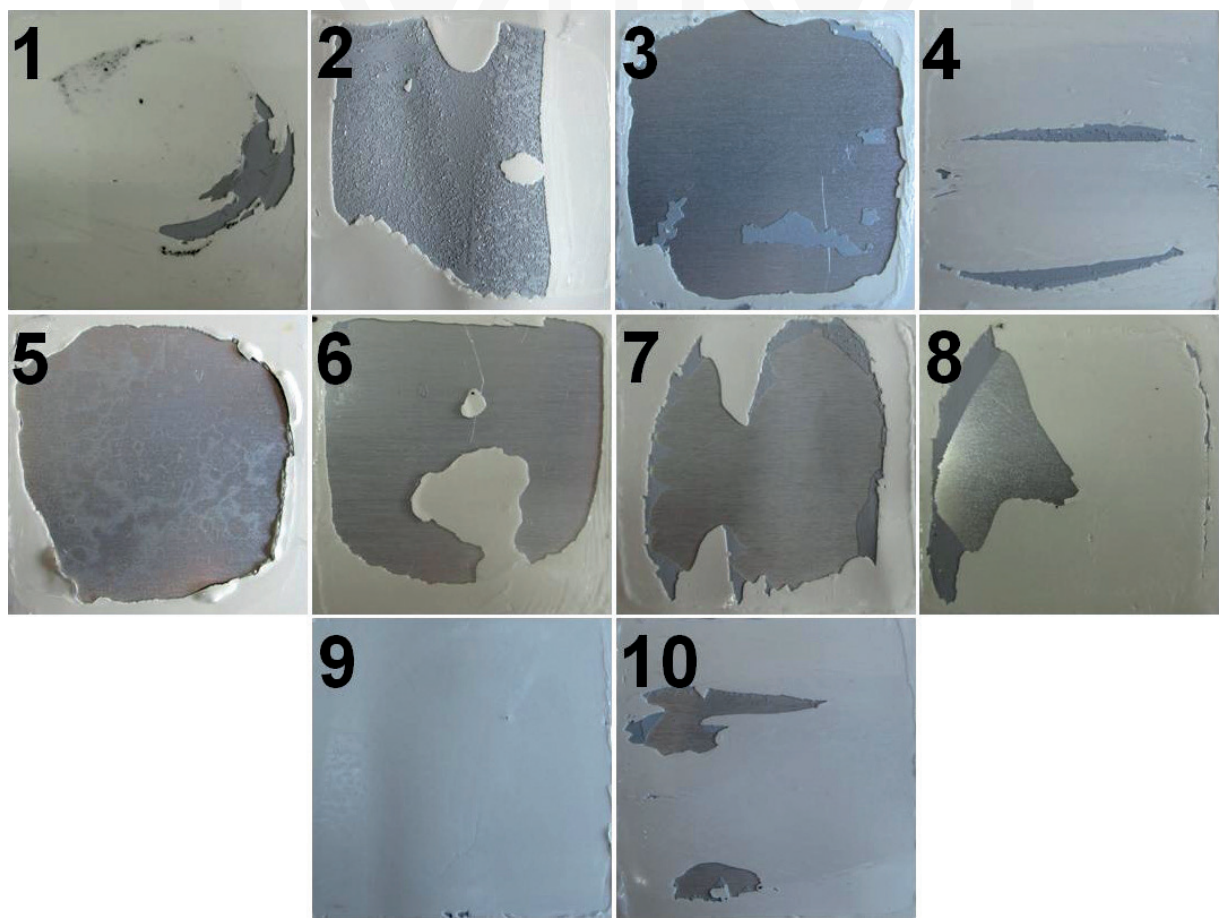

Fig. 2. The plate after study of coating detachment; 1 - reference sample, plate treated the preparation with 2 - N-methylpyrrolidone, 3 - dimethoxymethane 4 - dioxolane (gel), 5 - benzyl alcohol 6 - diethoxyethane, 7 - cyclohexanone ethylene ketal, 8 - benzaldehyde ethylene acetal, 9 - ipropoxyethane, 10 - dibutoxyethane 
In the case of the white plate only, dioxolane (emulsion) caused wrinkling of the shell. In four causes, the activity caused softening of the shell, making the detachment of the coating possible. We can see that, with increasing $\log \mathrm{P}$, the force, which is needed to detach the coating, increases from $151 \mathrm{~N}$ for dimethoxymethane $(\log \mathrm{P}-0.26)$ to $333 \mathrm{~N}$ for benzaldehyde ethylene acetal $(\log \mathrm{P} 1.63)$. The exception is diethoxyethane. For this compound, the force needed to detach the coating is $56.6 \mathrm{~N}$. A further increase of $\log \mathrm{P}$ makes the preparation not soften the coating. In this case, the adhesion forces of the paint to the base are stronger than the adhesion forces of the glue to the coating. Therefore, we cannot detach the whole shell, but only small fragments. Such a situation took place in the case of the reference sample and the sample with dipropoxyethane and dibutoxyethane.

\section{Green plate}

In the case of the green plate, all substances caused a significant reduction of the forces required to detach the coating. Only the preparation with $\mathrm{N}$-methylpyrrolidone did not cause a reduction of the forces required to detach the coating. However, it softened the coating, making it possible to remove all of the top layer.

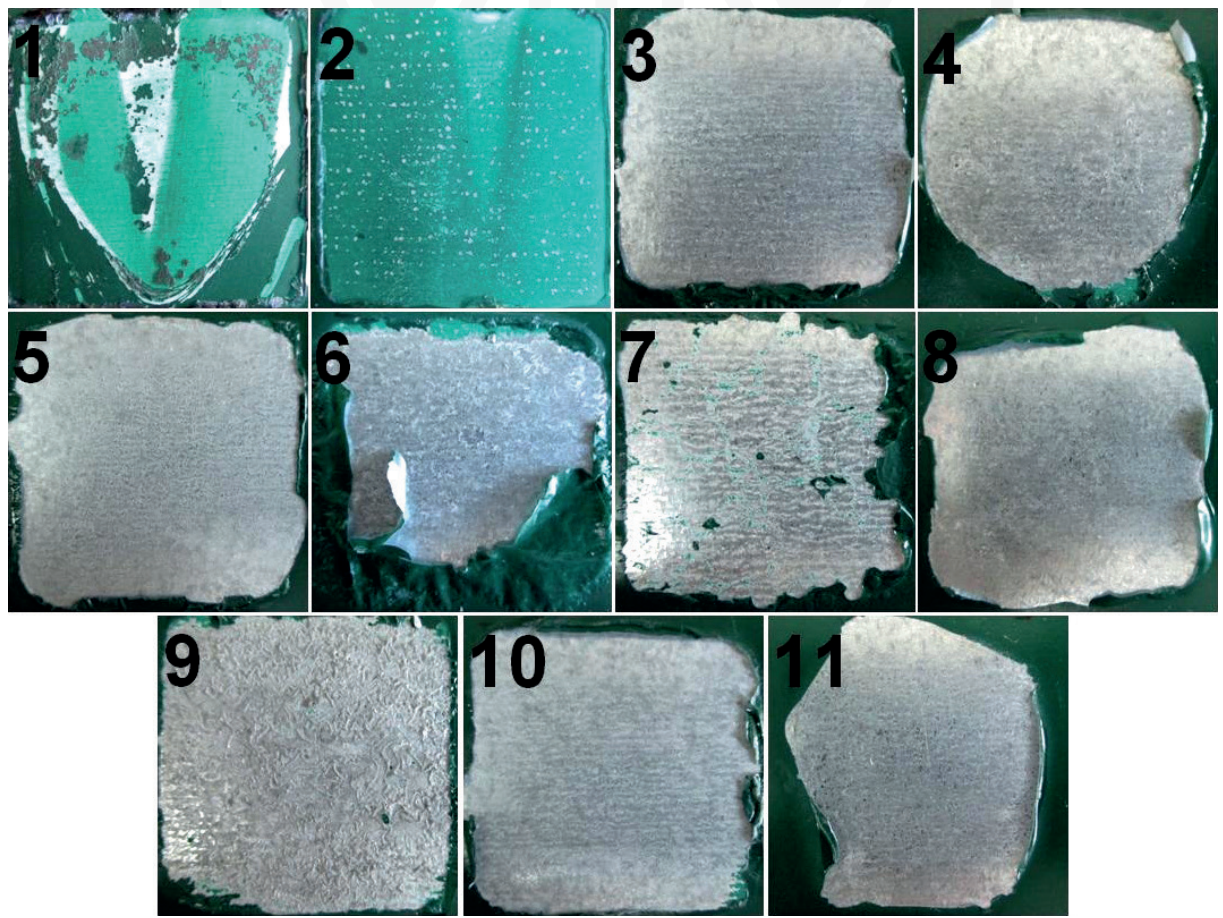

Fig. 3. The plate after study of coating detachment; 1 - reference sample, plate treated the preparation with 2 - N-methylpyrrolidone, 3 - dimethoxymethane 4 - dioxolane (gel), 5 - dioxolane (emulsion), 6 - benzyl alcohol 7 - diethoxyethane, 8 - cyclohexanone ethylene ketal, 9 - benzaldehyde ethylene acetal, 10 - dipropoxyethane, 11 - dibutoxyethane 
In this case, regardless of the partition coefficient, the substances caused wrinkling of the shell. The only exception is $\mathrm{N}$-methylpyrrolidone. In its case, despite a low value of partition coefficient, it did not cause wrinkling of the shell.

Table 5. Results of coating detachment study for the green plate

\begin{tabular}{|l|l|l|l|}
\hline \multirow{2}{*}{\multicolumn{1}{|c|}{ Active ingredient }} & \multicolumn{2}{c|}{ Force } & \multicolumn{1}{c|}{ Comments } \\
\cline { 2 - 3 } & \multicolumn{1}{|c|}{$\mathrm{kPa}$} & \multicolumn{1}{c|}{$\mathbf{N}$} & \multicolumn{1}{c|}{} \\
\hline- & 513.7 & 446.8 & A part of the coating was detached \\
\hline N-methylpyrrolidone & 567.4 & 510.7 & The first layer of the coating was detached \\
\hline Dimethoxymethane & 37.3 & 33.5 & The coating was wrinkled \\
\hline Dioxolane (gel) & 139.1 & 121.0 & The coating was wrinkled \\
\hline Dioxolane (emulsion) & 66.0 & 60.2 & The coating was wrinkled \\
\hline Benzyl alcohol & 89.1 & 77.5 & The coating was wrinkled \\
\hline Diethoxyethane & 120.8 & 108.7 & The coating was wrinkled \\
\hline Cyclohexanone ethylene ketal & 32.2 & 30.0 & The coating was wrinkled \\
\hline Benzaldehyde ethylene acetal & 66.5 & 56.4 & The coating was wrinkled \\
\hline Dipropoxyethane & 60.0 & 54.0 & The coating was wrinkled \\
\hline Dibutoxyethane & 58.8 & 54.7 & The coating was wrinkled \\
\hline
\end{tabular}

\section{Brown plate}

Table 6. Results of coating detachment study for the brown plate

\begin{tabular}{|l|l|l|l|}
\hline \multirow{2}{*}{\multicolumn{1}{|c|}{ Active ingredient }} & \multicolumn{2}{c|}{ Force } & \multicolumn{1}{c|}{ Comments } \\
\cline { 2 - 3 } & \multicolumn{1}{|c|}{$\mathrm{kPa}$} & \multicolumn{1}{c|}{$\mathrm{N}$} & \\
\hline- & 507.4 & 456.6 & A part of the coating was detached \\
\hline N-methylpyrrolidone & 754.5 & 679.0 & The first layer of the coating was detached \\
\hline Dimethoxymethane & - & - & The coating was wrinkled \\
\hline Dioxolane (gel) & 392.9 & 353.6 & The coating was wrinkled \\
\hline Dioxolane (emulsion) & 169.0 & 152.1 & The coating was wrinkled \\
\hline Benzyl alcohol & 8.3 & 7.4 & The coating was wrinkled \\
\hline Diethoxyethane & 305.8 & 275.2 & The coating was wrinkled \\
\hline Cyclohexanone ethylene ketal & 83.4 & 77.5 & The coating was wrinkled \\
\hline Benzaldehyde ethylene acetal & 37.4 & 34.8 & The coating was wrinkled \\
\hline Dipropoxyethane & 268.3 & 241.4 & The coating was wrinkled \\
\hline Dibutoxyethane & 173.1 & 155.8 & The coating was wrinkled \\
\hline
\end{tabular}

The same situation as in the green plate occurred in the case of the brown plate. We can see a decreasing force required to detach the coating, from $465 \mathrm{~N}$ for the reference sample, to $7.4 \mathrm{~N}$ for benzyl alcohol. The exception is a test in which the coating was treated with the preparation containing $\mathrm{N}$-methylpyrrolidone. In this case, the coating was not wrinkled. However, it softened the coating, making it possible to remove all of the top layer.

Similar in this case, regardless of the partition coefficient, the substances caused wrinkling of the shell. As a result, the force required to detach the coating was reduced. The only exception is $\mathrm{N}$-methylpyrrolidone. In its case, despite a low value of partition coefficient, it did not cause wrinkling of the shell. 

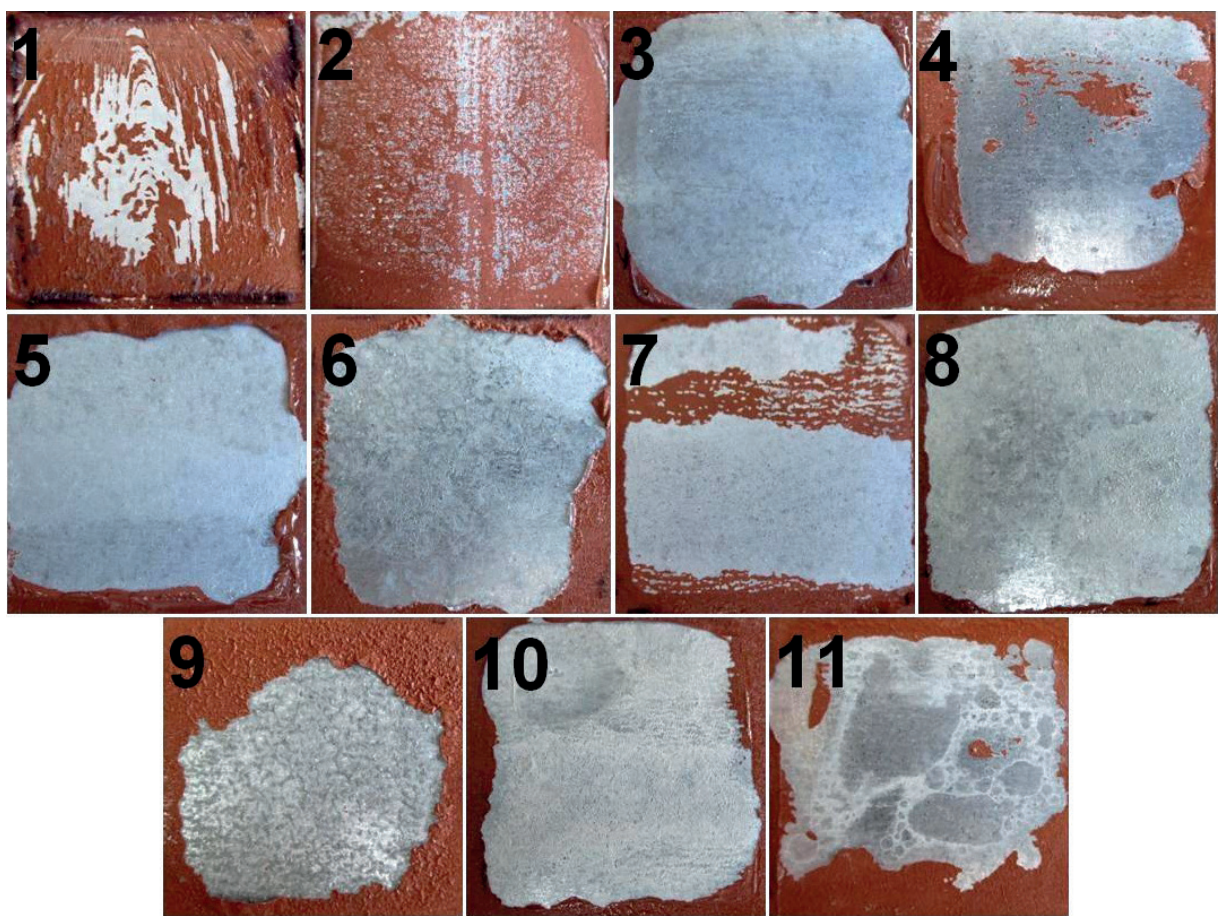

Fig. 4. The plate after study of coating detachment; 1 - reference sample, plate treated the preparation with 2 - N-methylpyrrolidone, 3 - dimethoxymethane 4 - dioxolane (gel), 5 - dioxolane (emulsion), 6 - benzyl alcohol 7 - diethoxyethane, 8 - cyclohexanone ethylene ketal, 9 - benzaldehyde ethylene acetal, 10 - dipropoxyethane, 11 - dibutoxyethane

\section{Epoxy plate}

Table 7. Results of coating detachment study for the epoxy plate

\begin{tabular}{|l|l|l|l|}
\hline \multirow{2}{*}{\multicolumn{1}{|c|}{ Active ingredient }} & \multicolumn{2}{c|}{ Force } & \multicolumn{1}{c}{ Comments } \\
\cline { 2 - 4 } & $\mathrm{kPa}$ & \multicolumn{1}{c|}{$\mathrm{N}$} & \multicolumn{1}{c|}{ A part of the coating was detached } \\
\hline- & 650.7 & 605.1 & A pact \\
\hline N-methylpyrrolidone & 194.6 & 181.0 & A small part of the coating was detached \\
\hline Dimethoxymethane & 63.0 & 52.9 & A part of the coating was detached \\
\hline Dioxolane (gel) & 249.6 & 224.6 & A part of the coating was detached \\
\hline Dioxolane (emulsion) & The coating was wrinkled \\
\hline Benzyl alcohol & The coating was wrinkled \\
\hline Diethoxyethane & 599.9 & 521.9 & A part of the coating was detached \\
\hline Cyclohexanone ethylene ketal & 249.3 & 224.2 & A part of the coating was detached \\
\hline Benzaldehyde ethylene acetal & 506.2 & 439.4 & A part of the coating was detached \\
\hline Dipropoxyethane & 411.0 & 369.9 & A part of the coating was detached \\
\hline Dibutoxyethane & 204.9 & 190.6 & A part of the coating was detached \\
\hline
\end{tabular}


In case of epoxy plate only dioxolane and benzyl alcohol caused wrinkling of the shell. In other cause substances caused softening of the shell. Thereby the force needed to detachment of the coating was less than in the case of coating didn't treat the preparation. In this case, we also can see that with increasing $\log \mathrm{P}$, the ability to wrinkling of the shell is decreased. However, this is not as pronounced as in the case of acrylic coatings.

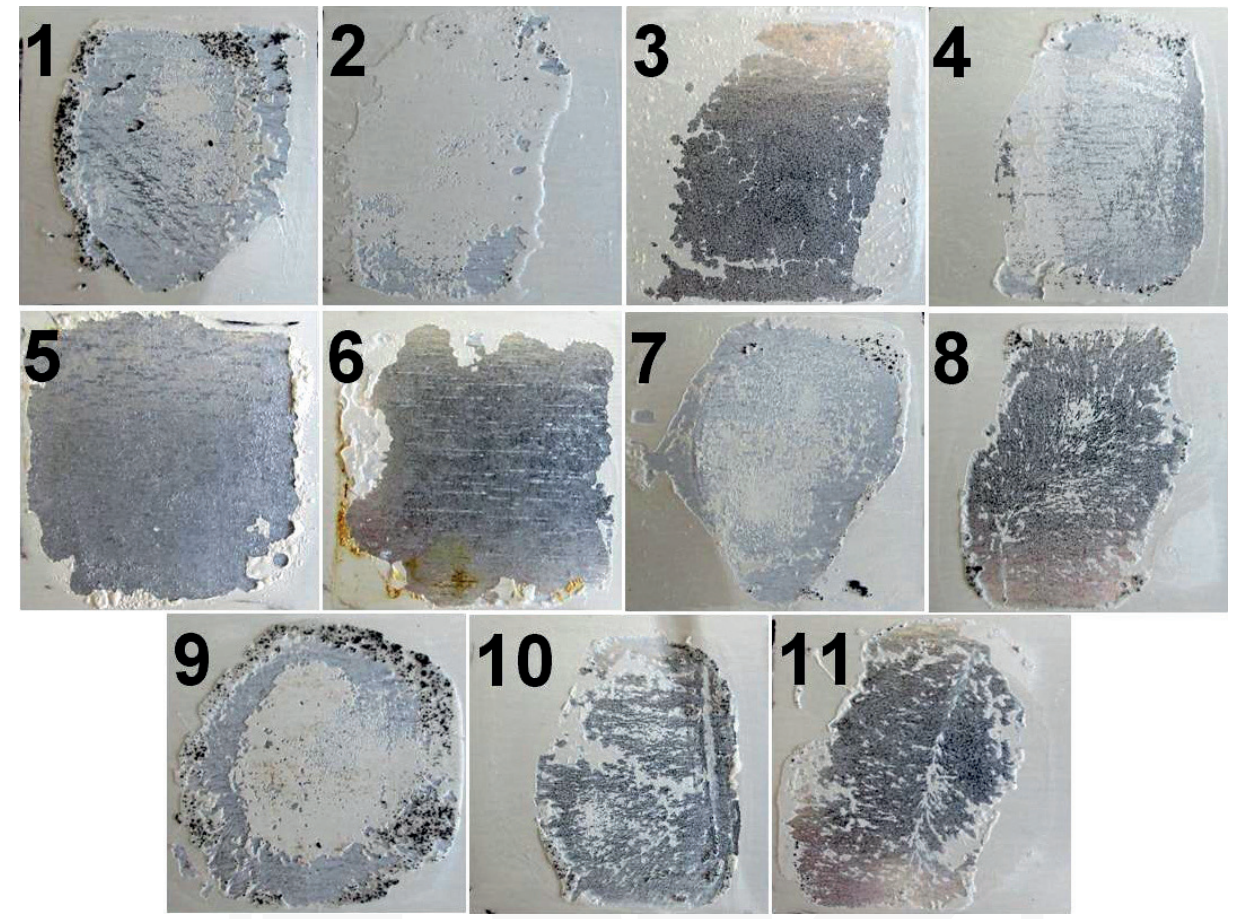

Fig. 5. The plate after study of coating detachment; 1 - reference sample, plate treated the preparation with 2 - N-methylpyrrolidone, 3 - dimethoxymethane 4 - dioxolane (gel), 5 - dioxolane (emulsion), 6 - benzyl alcohol 7 - diethoxyethane, 8 - cyclohexanone ethylene ketal, 9 - benzaldehyde ethylene acetal, 10 - dipropoxyethane, 11 - dibutoxyethane

\section{Conclusions}

All the used active substances caused softening or wrinkling of the shell. The best results were obtained on plates painted with melamine-formaldehyde paint. In the case of the green and brown plates, most of the test substances caused wrinkling of the shell. Thereby, the force needed to detach the coating was significantly lower than in the case of the reference sample. The exception is $\mathrm{N}$-methylpyrrolidone, which did not cause wrinkling of the shell in any of the cases. In the case of the plate with acrylic (blue and white) and epoxy coating, only dioxolane caused wrinkling of the shell. In the case of the blue plate, wrinkling of the shell was also caused by dimethoxymethane. In other cases, we observed softening of the coating. Additionally, we can see that, with an increase of the partition coefficient, the ability of wrinkling the shell is lower. The study shows that dioxolane and dimethoxymethane are the best substances to replace methylene chloride. 


\section{References}

[1] Decyzja Parlamentu Europejskiego i Rady zmieniająca dyrektywę Rady 76/769/EWG w zakresie ograniczeń we wprowadzaniu do obrotu i stosowaniu niektórych substancji i preparatów niebezpiecznych (dichlorometan).

[2] Patent no. US7087566, Dennis E Shireman, Paint removing composition, 08.08.2006.

[3] Patent no. US5932530, Georges Radu, Shizuo Maruyama, N-methylpyrrolidone, dimethyl ester and terpene-containing, paint removing composition, 03.08.1999.

[4] Patent no. US20060229220, Charles L Hawes, Dennis E Shireman, Color changing paint removing composition, 12.10.2006.

[5] Patent no. US6923873, Daniel Pageau, Elizabeth Marcu, David Aston, Paint stripping composition and method of using the same, 02.08.2005.

[6] Patent no. CA 2331439, Daniel Pageau, Elizabeth Marcu, David Aston, Paint stripping composition and method of using the same, 19.01.2001.

[7] Patent no. WO2008/142562, European Patent EP2152816A1, Biodegradable ecological paint remover, Michael Brailsford, 27.11.2008.

[8] Patent no. US2010326479, Michael Brailsford, Simon Mark Dormon, Paint remover, 30.12.2010.

[9] Patent no. US20050026799, Marvin Detar, Frederick Connelly, Water-based paint stripper, 03.02.2005.

[10] Patent no. US2010/0326479, Michael Brailsford, Simon Mark, Dormon, Paint remover, 30.12.2010.

[11] Australian Patent Application 2007902248, Michael Brailsford, Biodegradable ecological paint remover, 30.04.2007.

[12] Patent no. WO2006/071194, Anna Samuelsson, Agent to remove paint, lacquer, glue, plastic or similar from objects and use of it, 06.07.2006.

[13] Patent no. US6548464, James R Machac, Jr., Edward Chung-Yit Nieh, Susan A. Woodrum, Edward T Marquis, Pains stripper for aircraft and other multicoat systems, 15.04.2003.

[14] Patent no. US7485608, Daniel Perlman, pH-buffered alkylene carbonate nail polish and paint remover, 03.03.2009.

[15] Patent no. US20060058208, Mark Ventura, Steven Bolkan, Raymond F Ashley, Paint \& Ink remover two-phase system, 16.03.2006.

[16] Patent no. US6417149, Gerald Wojcik, Paint stripping composition and process containing methyl benzoate and formic acid, 09.07.2002.

[17] Patent no. US6624222, Paul E Kestyn, Augustin T Chen, Hong Zhao, Environmentally safe paint stripper emulsion, 23.08.2003.

[18] Patent no. US6790891, Paul E Kestyn, Augustin T Chen, Hong Zhao, Environmentally safe paint stripper, 14.08.2004.

[19] Patent no. WO2010/084159, European Patent EP2384359A1, Stripping composition, Arnaud Bourdette, Jean-Emile Zanetto, Patrick Lasnet de Lanty, 29.07.2010.

[20] Patent no. US6159915, James R Machac, Jr, Edward T Marquis, Susan A. Woodrum, Katty Darragas, Paint and coating remover, 12.12.2000. 
[21] Patent no. US6395103, James R Machac, Jr, Edward T Marquis, Susan A. Woodrum, Degreasing compositions, 28.05.2002.

[22] Patent no. EP2345702, Ramon Valls, Joaquin Bigorra Llosas, Elisabet Graupera, Javier Raya, Paint and coating remover compositions, 20.07.2011.

[23] Patent no. US7482316, Neil R Wilson, Michael A Murphy, Jr., Water-based flushing solution for paint and other coatings, 27.01.2009.

[24] Patent no. EP1918322A1, Kathryn Ellen Foster, Michael Scott Ciemiega, Paint stripper with corrosion inhibitor for aluminum, 31.10.2007. 